\title{
Disaster Management and Post-quake Impact on Tourism in Nepal
}

\author{
Him Lal Ghimire*
}

\begin{abstract}
Tourism, a large and unique collection of industry sectorsis an expanding worldwide phenomenon. By the next century, tourism will be the single largest industry in the worldwith special needs in disaster planning and recovery. Tourism is vulnerable sectorthat has been experiencing major crises from disasters. No tourist destination is immune to such crisis. Nepal is one of the world's 20 most disaster-prone countries where earthquakes are unique challenges for tourism.Nepal has to be very optimistic about the future of tourism as it has huge potentials to be the top class tourist destinations. Nepal should target to the global tourism market and take serious efforts to convince foreigners to visit Nepal and revive immediately. The Nepali tourism industry requires a strategy that will help manage crises and rapidly implement recovery strategies.
\end{abstract}

Keywords: Vulnerable, disasters. challenges, strategies, mitigation.

\section{Context}

Tourism is an expanding worldwide phenomenon, and has been observed that by the next century, tourism will be the single largest industry in the world. Today, tourism is also the subject of great media attention (Ghimire, 2014: 98). It has been experiencing major crises from disasters such as earthquakes, storm, tsunami, terrorist attacks, political instability, and economic recession. No tourist destination is immune to such crisis. The tourism business around the globe is one of the most susceptible and vulnerable sectors. In Nepal, thousands of tourists, tourism entrepreneurs and tourism products were affected and damaged or destroyed by the 7.8 earthquake on April 25, 2015. Earthquakes occur with no warning and is unpredictable. Mostly, tourists plan their trips in advance and travel a long distance from their home. That is why, tourism activities cannot be closed in advance, nor can tourists be evacuated easily in case of emergency(Ghimire, 2015).

\footnotetext{
* Dr. Ghimire has Ph.D. on "Pilgrimage Tourism Special Focus on Lumbini" from Tribhuvan University, Master of Science in Leadership for Educational Change (MSEd) from Bank Street College of Education, New York, a tourism writer and an educationist, statistician and academic leader with more than 27 year of experience in school/college management. Has published 100's of articles in international and national journals, newspapers and magazines. email: himghimire@gmail.com
} 
Nepal is one of the world's 20 most disaster-prone countries. Due to its location on the Alpide belt (Alpine-Himalayan), the country is highly susceptible to damage from a wide range of natural disasters including floods, landslides, and earthquakes. Contributing to the high risks are factors such as a lack of synchronization amongst government agencies, poor infrastructure, lack of public awareness, and rampant poverty, challenges that Nepal must face in improving its disaster preparedness (NDMRH, 2015: 26).The two mega quakes and their large families of aftershocks that are still showing their presence around have been great teachers for the Nepalese people. What is required, though, is deep insight, a strong motivation to learn and dedication to implement what is decided at the central level of disaster management. In fact, this was an opportunity for the government of Nepal, leadership and local bodies to test their capacity to handle the crises of this magnitude. But managing things has not been smooth. Managing a disaster of any scale or managing everything in a proper, systematic and agreeable way has been a challenge for a country like Nepal.

Tourism is a large and unique collection of industry sectors with special needs in disaster planning and recovery. Tourism is especially vulnerable to disasters and, being fragmented, often its response is difficult to initiate and coordinate (Mistilis\& Sheldon, 2005). This paper attempts to explain disaster management techniques and present the modules for disasters management. It also highlight the impacts of devastating earthquakes and suggest the frameworks and guidelines to revive tourism in Nepal.

\section{Importance of Tourism}

Tourism is one of the driving forces of economic development in industrialized, less-developed and developing countries. TRM (2006) writes that travel and tourism industry contributes substantially to:

- strong economic growth,

- creation of skilled and semi-skilled jobs,

- greater export returns,

- foreign investments and currencies, and

- economic well-being and social stability.

Tourism plays a vital role in world business. Travel and tourism is one of the world's largest industries and generators of jobs. The tourism industry provides a wide range of employment opportunities, especially for women and young people, helping to break the vicious cycle of poverty by enhancing human capital and creating new prospects for future generations. The jobs are spread across a wide range of industries and comprise a broad range of remuneration levels. The development of small and medium size enterprises creates work for unskilled and skilled workers in existing centers and rural areas. Visitors' expenditure in a destination flows directly to industries 
that serve visitors and indirectly to the many other businesses that supply goods and services to these tourism businesses. In this way, the benefits from visitors' expenditure flow right through local, regional, state/provincial and national economies and throughout communities (TRM, 2006). With global climate change, rapid economic development and accelerated urbanization, the pressures from resources, environment and ecology have been intensified on most countries in the world. In recent years, frequent world-wide natural disasters have brought about huge devastation to human society, life and property (Ying, 2011: 1). Many sectors of tourism, such as visitor arrivals, employment, private sector profits, and government revenues and eventually further investment, can be impacted negatively when a disaster occurs in a tourism destination (Huang etal,, 2008; in Ying, 2011: 2). Therefore, a promising sunrise industry that inevitably has to grow with disasters if it is to succeed has been attracting increasing scrutiny about its crisis management from the academic perspective. For many years scholars and experts have been constructing generic models of tourism crisis and disaster management, specifically since "models suggest that a strategic management and planning approach to crisis and disaster management can be beneficial for tourism planners and managers" (Ritchie, 2004; in Ying, 2011: 2).

Earthquakes are unique challenges for tourism, especially for a country like Nepal. Earthquakes occur with no warning and is unpredictable. Mostly, tourists plan their trips in advance and travel a long distance from their home. That is why, tourism activities cannot be closed in advance, nor evacuated tourists easily in case of emergency. The tourism business around the globe which is one of the most susceptible and vulnerable sectors has been experiencing major crises from disasters such as earthquakes, storm, tsunami, terrorist attacks, political instability, and economic recession. Generally, disasters are large non-controllable problems that evaluate the capability of nations and communities to effectively protect the population and its ability to recover after the disasters. No tourist destination is immune to such crisis. Tourism is an expanding worldwide phenomenon, and it has been observed that by the next century, tourism will be the single largest industry in the world. Today, tourism is also the subject of great media attention.

Tourism involves elements of uncertainty and unpredictability that have always been in a way, part of its attraction. Distance travelling has always involved risks, but the difference now is that those risks are progressively more evident (Moreira, 2007; in Kunwar and Limbu, 2015 p.16). Despite the huge importance and potentials of tourism industry, it has been highly affected by the natural disasters, national and international incidents, quality of services, security and many more. If it is managed properly, millions of opportunities are created and can cope with the risks, crisis and challenges. An interesting explanation could be noticed that two characters "wei ji" in the following figure has been widely adopted to illustrate the word "crisis" in China. The combination of these two characters form the meaning of crisis, Chinese language, 
however, "wei" stands for "threat" while "ji" refers to "opportunity". This Chinese word is well in accordance with the view that a crisis can be regarded as a turning point for changing an existing system. The results might lead to change for the individuals, organizations or even for whole countries. How to mitigate the negative losses coming from the "threat" while taking advantage of the "opportunity" has been paid much attention from academics and practitioners (Ying, 2011:20).

Figure 1: Threat and Opportunity in Two Chinese Characters

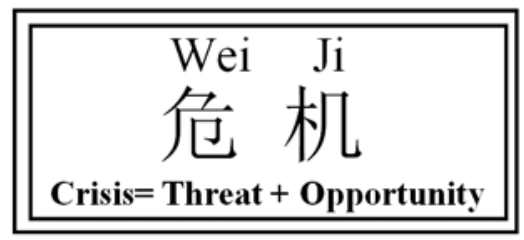

Source: ISDR 2004; in Ying, 2011: 20.

Crises and disasters are related but different events. Disasters or catastrophes imply a clearly unpredictable event that can normally responded to after the event (Glaesser, 2003; in Kunwar 2015). Crisis have been described as the possible but unexpected result of management failures that are concerned with future course of events set in motion by human action or inaction precipitating the event (Prideaux et al., 2003; in Kunwar, 2015).

\section{Vulnerability}

One of the important factor that contributes to disaster risks is vulnerability, which is the susceptibility of people, properties and livelihoods to the damaging effects of the hazard. Historical damage and loss data provides insights on the vulnerability of people and assets in Nepal. A large proportion of destructive disasters in Nepal are small-scale disasters, averaging more than $90 \%$ of all disasters, which cause more death; affects more people; destroy more houses; and cause more economic damages, as compared to large but infrequent disasters. This shows that there is very high vulnerability of both people and assets in Nepal. The Pacific Disasters Center ranks Nepal as 37 out of 172 countries in its disaster vulnerability index (UNISDR (2015).

\section{Risk}

UNEP (2008) writes that risk is most commonly held to mean something to be avoided; in everyday usage, risk is associated with the probability of a loss. In the framework of "disaster risk management" risk is defined as "the probability of harmful consequences, or expected losses (deaths, injuries, property, livelihoods, economic activity disrupted or environment damaged) resulting from interactions between 
natural or human-induced hazards and vulnerable conditions". Risk may also be computed as the product of a disaster's probability multiplied by the vulnerability and divided by the capacity to adequately respond.

$$
\text { Risk }=\frac{\text { (Probability of a disaster X Vulnerability) }}{\text { Capacity }}
$$

The equation shows that larger the capacity to respond the lower would be the risk. Therefore two main and complimentary approaches to reducing risk are:

- Decreasing vulnerability

- Increasing capacity

Based on the above, it is generally agreed that the impacts of disasters can be substantially reduced if vulnerable communities are fully informed about possible hazards and have participated in the formulation of risk and crisis management plans - that is their capacity to respond is greater.

\section{Disasters}

Oxford dictionary defines disaster as a sudden accident or a natural catastrophe that causes great damage or loss of life. IFRC (2015) writes "disaster is a sudden, calamitous event that seriously disrupts the functioning of a community or society and causes human, material, and economic or environmental losses that exceed the community's or society's ability to cope using its own resources. Though often caused by nature, disasters can have human origins". Disasters can take many different forms, and the duration can range from an hourly disruption to days or weeks of ongoing destruction. A disaster occurs when a hazard impacts on vulnerable people.

$$
\text { Disaster }=\frac{(\text { Hazard }+ \text { Vulnerability })}{\text { Capacity }}
$$

The combination of hazards, vulnerability and inability to reduce the potential negative consequences of risk results in disaster (ibid, 2015).It is acknowledged that due to population growth, increased urbanization, greater use and dependence on technology and globalization, disasters are becoming more frequent and geographically diverse (Pelling, 2003; in Biran et al.; 2014)

\section{Types of Disasters}

Natural disasters are out of human control. Hurricanes and tropical storms are among the most powerful natural disasters. Tornadoes are relatively brief but violent. Both earthquakes and tornadoes strike suddenly without warning. Flooding is the most common of natural hazards, and requires an understanding of the natural systems of our environment, including floodplains and the frequency of flooding events. Disasters are also caused by human activities. Hazardous materials emergencies include 
chemical spills and groundwater contamination. Workplace fires are more common and can cause significant property damage and loss of life. Cyber-terrorism involves attacks against computers and networks done to intimidate or coerce a government or its people for political or social objectives. Man-made disaster becomes sometimes more harmful than the natural disaster for a country like Nepal. Below is a list of the various types of disasters - both natural and man-made or technological in nature that can impact a community.

Table 1: Types of disasters

\begin{tabular}{|l|l|l|}
\hline Geophysical & \multicolumn{1}{|c|}{ Natural } & Man-Made and Technological \\
\hline & Landslides and debris flow & $\begin{array}{l}\text { Nuclear power plant and } \\
\text { nuclear blast }\end{array}$ \\
\hline & Tsunamis & $\begin{array}{l}\text { Radiological emergencies } \\
\text { biological weapons }\end{array}$ \\
\hline & Volcanic activity & Cyber attacks \\
\hline Hydrological & Avalanches & Explosion \\
\hline & Floods and flash floods & Civil unrest/war \\
\hline Climatological & Extreme temperatures & Terrorism \\
\hline & Drought and water shortage & Criminal activities \\
\hline & Wildfires & Industrial accidents \\
\hline Meteorological & Cyclones & Transport accidents \\
\hline & Storms/wave surges and lighting & Displaced populations \\
\hline Biological & Disease epidemics & Emergencies/conflicts \\
\hline & Insect/animal plagues & $\begin{array}{l}\text { IT /Telecommunication } \\
\text { System failure }\end{array}$ \\
\hline
\end{tabular}

Source: IFRC, 2015 and internet search

Nepal has been suffering with political instability and conflicts for more than 20 years. Lastly, strikes, blockades and protests against Nepal's new constitution have cost the economy more than $\$ 1$ billion - just months after the country was struck by a series of devastating earthquakes. The crisis as the country's worst economic disaster. The economy has been completely stalled for the past couple of months and the impact is worse than the earthquake. Things have become unbearable for the tourists and negatively affecting the tourism in Nepal because of blockage in Nepal India boarder and fuel crisis. Two of the most important historic sites, the Chitwan National Park 
and the Lumbini - the place where Buddha was born - have become red zones. Taxi fares have gone up almost $1000 \%$, and restaurants are no longer operating due to the lack of gas. Some hotels report only $10 \%$ occupancy rate in contrast with the $90 \%$ rate expected during this time of the year. Since tourism in Nepal is an important source of income for the government, the current crisis only worsens the dire economic situation of the country (Tourism review, 2015).

\section{The Disaster Management Cycle}

A disaster involves hazards which can be detrimental to human life and property e.g. floods, earthquakes, tsunamis, high winds, intense rainfall or drought. These hazards can affect the entire community or selective areas, such as the coastline or floodplain, as part of one or more natural events. The impacts are potentially disastrous when the capacity of the responders is severely tested or exceeded, as in a catastrophic event.The disaster management cycle, also referred to as the emergency management cycle, involves 4 phases such as Prevention, Preparedness, Response and Recovery(UNEP (2008: 29).

Figure 2: The Disaster Cycle

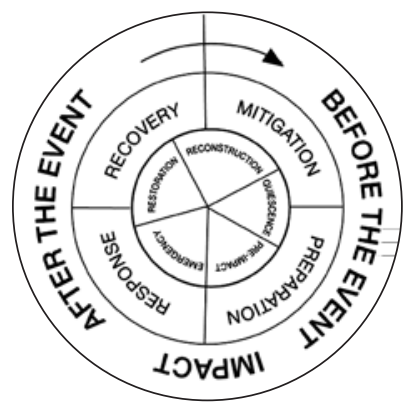

Source: "Principles of Emergency Planning \& Management" by D. Alexander (Harpenden: Terra Publishing, 2002); in UNEP, 2008: 29).

The "prevention" phase includes mitigation and risk reduction associated with new construction, planning and redesign of infrastructure, processes and activities for climate-proofing tourism destination and increasing resilience againstdisasters. In fact, these prevention activities should be considered earlier on in the design, construction, and refurbishment phases of tourism infrastructure development. The "preparedness" or pre-impact phase includes all tasks and activities that build the capacity of the community for an effective and organized response. The "response" phase constitutes all actions geared towards stabilization, containment or control of crisis or emergency conditions. The "recovery" phase refers to a reinstatement of normal or near normal conditions following a disaster event and includes repair, 
restoration or reconstruction of damaged or destroyed homes, facilities and infrastructure. Traditionally, the term 'emergency response' has been used in a reactive sense to describe a community's typical response after a disaster has struck. This approach has largely been replaced by the more proactive practice of 'managing' disasters.'Disaster management' is a continuum of all the phases mentioned above. This continuum is especially relevant for prevention in that it can occur in all phases of the disaster management cycle. Disaster management defines an approach that seeks to understand the full range of impacts, identifies the risks to people, their livelihoods and property. Further, it develops preparedness and response measures to reduce exposure, improve capacity and hence to limit the likelihood of a future disaster or its impacts (UNEP, 2008: 30).

Taken together, these elements are not static, but revolve around a continuous cycle of activity and interlocution among the responsible and collaborating agencies, united by a common objective to reduce the probability for disaster occurrence. In order for the responsible agency to prepare and respond effectively, there needs to be an analysis of the key disaster risks that threaten the destination. UNEP (2008) has highlighted five basic sequential tasks to be undertaken for disaster management:

- Identifying hazard risks: analyzing hazards resulting from a natural or manmade event, along with an understanding of the full range of probable effects and consequences.

- Assessing a community's vulnerability to the risk: a community's vulnerability may be measured in terms of its size, geographic location, economic status, level of organization, and available resources; infrastructure, and response capability, among other factors. Its vulnerability will therefore depend upon the level of exposure and its capacity to adapt, respond to or recover from the hazard.

- Developing a preparedness and mitigation plan: a plan to address any institutional or systemic weaknesses, which could limit the destination or community's ability to mitigate disaster risks.

- Implementing the plan: implementation may be simulated to ensure that the plan is workable during real disaster conditions. It is also important to document the lessons learned from the exercises in order to assemble a databank of learning, experience and information.

- Monitoring, evaluating, revising and updating the plan: the information assembled provides essential learning for revising and updating the plan, correcting any areas of weakness or ineffectiveness, reallocating resources for greater efficiency and improving community resilience overall.

Organizing the disaster management capability at tourism destinations is principally the responsibility of national and local governments. However, disaster management 
policies and responsibilities are often enshrined in national laws. These provide the overarching legislative framework through which states and local governments receive the authority to implement their response strategies (ibid, 2008: 31).

\section{Disaster Risk Reduction Framework}

Faulkner (2001) developed a comprehensive framework to describe stages of community response and a generic framework for tourism disaster strategies. He gave a framework with five phases in disaster process, which are pre-event, prodromal (disaster imminent), emergency, intermediate and long-term recovery. Each is linked to elements of the disaster management response (precursors, mobilization, action, recovery, reconstruction, reassessment and review) and to principal ingredients of the disaster management strategies (risk assessment and disaster contingency plans). The elements of Faulkner's framework that immediately relate to knowledge management are risk assessment, prioritization protocols, community capability audit, disaster management command center, media and monitoring activities, warning systems, flexibility and involvement education and review.

Figure 3: A Framework For Disaster Risk Reduction

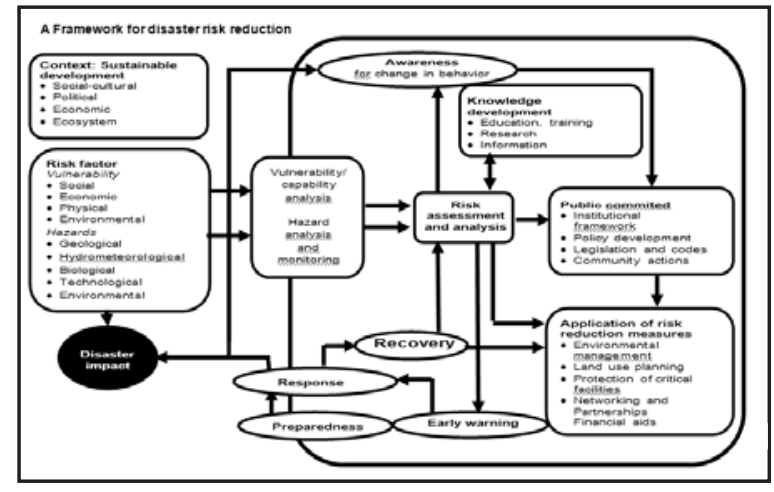

Source: UNEP, 2008: 43.

The above figure graphically presents the typical network of inter-related activities required for disaster risk reduction. The main message of it is working to achieve destination resilience requires an understanding of and a commitment to systematically undertaking the major work items in this diagram (UNEP, 2008: 42).

\section{Tourism and Risk Management}

TRM (2006) points out two fundamental roles for tourism in risk management: the first of these is as a partner with government and community agencies in the development of multi-agency, coordinated disaster management plans, systems, procedures and processes which include the needs of tourism; the second is to develop 
plans and procedures appropriate to a destination and to the specific roles and responsibilities of an organization, to train personnel to those plans, and to conduct regular tests of plans, procedures and personnel with subsequent amendment and updating. No organization involved in disaster management should work in isolation. Each tourism operator and organization is part of the disaster management community and should function within the established, coordinated and integrated system. The development of effective plans and procedures in the disaster management context is dependent upon:

- regular inter-agency meetings, networking and liaison;

- implementation of a disaster risk management process;

- development of plans and procedures;

- establishment and nurturing of partnerships;

- community consultation;

- effective communication;

- training of personnel;

- testing of plans, procedures and personnel through exercises (simulated disaster activities); and

- efficient review and amendment procedures.

TRM (2006) further writes that the disaster management system in each country will have allocated roles and responsibilities for the management of disasters. It is not the responsibility of the tourism industry to assign these responsibilities or to allocate tasks to disaster management agencies. Rather, they should work within the established framework to add value to the overall outcomes. Different sections of the tourism industry will have different responsibilities in disaster management, and will need to liaise at different levels of the disaster management system. National or state/provinciallevel tourism authorities should participate through membership of appropriate committees, in national and state/provincial-level disaster risk management processes, contributing to the development of policy and strategic planning processes. An individual tourism operator should contribute, again through appropriate committees, to local-level disaster management processes, including the development of response and recovery plans for the community, and plans and procedures for tourism facilities. At all levels, disaster management is a multi-agency system. The second fundamental role for tourism in risk management is to be proactive and develop strategies for a destination or an individual business/organization to maximize the potential for continuity of normal business and to protect the safety and security of visitors and staff in the event of a disaster or crisis. The development and implementation of tourism risk management strategies which comprehensively address potential risks to tourism are now becoming an integral part of managing tourism in destinations. 
These tourism risk management strategies should link to community disaster management plans and include actions which tourism operators and organizations can take to complement the work of community disaster management agencies.

Risk management plans for tourism should provide, as appropriate and as a minimum, for:

- the safety of visitors and employees;

- secure systems to communicate with all persons within the facility and within the destination;

- security of buildings, facilities and equipment from the effects of the disaster;

- contributing trained liaison personnel to the disaster management agencies during response and recovery operations, as required;

- supplying resources to support response and recovery operations; and

- procedures for return to normal business activities upon termination of the disaster operations.

\section{Natural Disasters in Nepal}

Natural disasters are common in Nepal. The damage and negative impacts of April 25, 2015 devastating earthquakes and its aftershocks are significantly large in the history of Nepal. The casualties were over 8,790 and 22,300 people were injured. It is estimated that lives of eight million people (almost one-third of the population of Nepal), have been impacted by these earthquakes. Thirty-one of the country's 75 districts have been affected, out of which 14 were declared 'crisis-hit' for prioritizing rescue and relief operations; another 17 neighbouring districts were partially affected (NPC, 2015: 11). In 20114, Nepal faced landslide creating blockage in SunkoshiRiver (killed 156, injured 27 and displaced 436 people), avalanches in Mt. Everest (killed 25 men mostly Sherpa) and blizzards and avalanches in Annapurna circuit (killed 29)that hampered largely in Nepalese tourism industry. Among all of the other challenges in the development of tourism in Nepal, the natural disasters are the major challenges to be faced (Kunwar, 2015: 24).

The humanitarian challenge became immediately apparent as millions of people whose houses were either destroyed and those who were fearful of imminent aftershocks started camping out in the open. This put a tremendous demand on the government and philanthropic associations for materials to erect makeshift shelters and to supply essentials. More than a month after the disaster, tens of thousands of people are still reported to be living either in temporary or transitional shelters in spaces presumed to be safe from landslide and rain. The distribution of relief materials proved challenging because of the remoteness of many villages, rugged terrain, threat of landslides, and logistical diffculties (NPC, 2015: 13). 
Table 2: Summary of Disaster Effects

\begin{tabular}{|c|c|c|c|c|c|c|}
\hline & \multicolumn{3}{|c|}{$\begin{array}{l}\text { Disaster Effects } \\
\text { (NPR Million) }\end{array}$} & \multicolumn{2}{|c|}{$\begin{array}{l}\text { Distribution of } \\
\text { Disaster Effects } \\
\text { (NPR million) }\end{array}$} & \multirow[t]{2}{*}{$\begin{array}{c}\text { Losses } \\
\text { in } \\
\text { persona } \\
\text { income } \\
\text { (NPR } \\
\text { million) }\end{array}$} \\
\hline & Damages & Losses & Total & Private & Public & \\
\hline Social Sectors & 355,028 & 53,597 & 408,625 & 363,248 & 45,377 & - \\
\hline $\begin{array}{l}\text { Housing and Human } \\
\text { Settlements }\end{array}$ & 303,632 & 46,908 & 350,540 & 390,540 & - & - \\
\hline Health & 6,422 & 1,122 & 7,544 & 1,394 & 6,190 & - \\
\hline Education & 28,064 & 3,254 & 31,318 & 2,365 & 28,953 & - \\
\hline Cultural Heritage & 16,910 & 2,313 & 19,223 & 8,948 & 10,274 & - \\
\hline Productive Sectors & 58,074 & 120,046 & 178,121 & 158,079 & 20,043 & 17,124 \\
\hline Agriculture & 16,405 & 11,962 & 28,366 & 25,813 & 2,553 & 4,603 \\
\hline Irrigation & 383 & & 383 & - & 383 & \\
\hline Commerce & 9,015 & 7,938 & 16,953 & 16,953 & - & 2,667 \\
\hline Industry & 8,394 & 10,877 & 19,273 & 19,271 & - & 3,654 \\
\hline Tourism & 18,863 & 62,379 & 81,242 & 75,106 & 6,137 & 6,200 \\
\hline Finance & 5,015 & 26,890 & 31,905 & 20,937 & 10,969 & - \\
\hline Infrastructure Sectors & 52,460 & 14,323 & 66,783 & 17,281 & 49,502 & \\
\hline Electricity & 17,807 & 3,435 & 21,242 & 15,569 & 5,673 & - \\
\hline Communications & 3,610 & 5,085 & 8,695 & 1,712 & 6,983 & \\
\hline Community Infrastructure & 3,349 & - & 3,349 & - & 3,349 & - \\
\hline Transport & 17,188 & 4,930 & 22,118 & - & 22,118 & \\
\hline Water and Sanitation & 10,506 & 873 & 11,379 & - & 11,379 & - \\
\hline Cross-Cutting issues & 51,872 & 1,061 & 52,933 & 1,755 & 51,178 & - \\
\hline Governance & 18,757 & - & 18,757 & - & 18,757 & - \\
\hline Disaster Risk Reduction & 155 & - & 155 & - & 155 & - \\
\hline Environment and forestry & 32,960 & 1,061 & 34,021 & 1,755 & 32,267 & - \\
\hline Total & 517,434 & 189,027 & 706,461 & 540,362 & 166,100 & 17,124 \\
\hline Total \{US\$ million) & $\$ 5,174$ & $\$ 1,890$ & $\$ 7,065$ & $\$ 5,404$ & $\$ 1,661$ & $\$ 171$ \\
\hline
\end{tabular}

Source: (NPC, 2015). 


\section{Devastating Earthquake's Impacts on Tourism}

Nepal's tourism sector has suffered losses worth Rs 44 billion in the aftermath of the devastating earthquake and its aftershocks. These disasters have heavily damaged the infrastructure of tourism in Nepal, affecting not only the mountaineering, trekking and tour businesses, but also, many cultural heritage sites, shrines, pagodas, temples and archaeological sites-properties over hundreds of years old (Ghimire, 2015).The earthquake affected about 2,900 structures with a cultural and religious heritage value. Major monuments in Kathmandu's seven World Heritage Monument Zones were severely damaged and many collapsed completely. In addition, in more than 20 districts, thousands of private residences built on traditional lines, historic public buildings as well as ancient and recently built temples and monasteries were affected by the earthquakes, 25 percent of which were destroyed completely. The total estimated damages to tangible heritage amounts to NPR 16.9 billion (US\$ 169 million) (NPC, 2015).

Table 3: Summary of Damage and Losses

\begin{tabular}{|l|r|r|r|r|r|}
\hline \multicolumn{1}{|c|}{ Subsector } & \multicolumn{3}{c|}{$\begin{array}{c}\text { Disaster Effects } \\
\text { (NPR Million) }\end{array}$} & \multicolumn{2}{c|}{$\begin{array}{c}\text { Share of Disaster } \\
\text { Effects }\end{array}$} \\
\hline & Damages & Losses & Total & $\begin{array}{c}\text { Private/ } \\
\text { Community }\end{array}$ & Public \\
\hline Heritages sites in 16 districts & 7,875 & 1,409 & 9,284 & - & 9,284 \\
\hline $\begin{array}{l}\text { Monasteries \& historic } \\
\text { structures (older than 100 years) }\end{array}$ & 5,300 & 530 & 5,830 & 5,830 & - \\
\hline $\begin{array}{l}\text { Monasteries \& historic } \\
\text { structures (less than 100 years) }\end{array}$ & 2,835 & 283 & 3,118 & 3,118 & - \\
\hline Temples in remote areas & 900 & 90 & 990 & & 990 \\
\hline Total & $\mathbf{1 6 , 9 1 0}$ & $\mathbf{2 , 3 1 3}$ & $\mathbf{1 9 , 2 2 3}$ & $\mathbf{8 , 9 4 8}$ & $\mathbf{1 0 , 2 7 4}$ \\
\hline${ }^{\star}$ Almost all the monasteries are under community ownership and management \\
\hline
\end{tabular}

Source: (NPC, 2015).

The overall impact of the earthquake on the tourism sector goes beyond the 14 affected districts, which have suffered signifcant physical damage to well-known tourist destinations like Chitwan and Pokhara in terms of a sharp fall in the number of tourists. The negative repercussions of the disaster are likely to translate into a reduced number of tourist arrivals over the next few years, reduction in tourist spending per day from US $\$ 43$ to US $\$ 35$ (as per industry sources), which will signifcantly affect revenues. Other nations that have experienced similar disasters have generally taken several years to recover fully with regard to tourist arrivals. It is estimated that the overall impact of the earthquakes on the Nepali tourism industry will be a reduction 
of about 40 percent on average over the next 12 months, and a 20 percent reduction in the next 12 to 24 months (NPC, 2015).

Table 4: Summary of Damages and Losses

\begin{tabular}{|l|r|r|r|r|r|}
\hline \multicolumn{1}{|c|}{ Subsector } & \multicolumn{2}{c|}{ Disaster Effects (NPR Million) } & Share of Disaster Effects \\
\hline & Damages & Losses & Total & Private & Public \\
\hline Hotels and others & 16,295 & - & 16,295 & 16,295 & - \\
\hline Homestays & 1,720 & 495 & 1,720 & 1,720 & - \\
\hline Eco-lodges & 415 & - & 415 & 415 & - \\
\hline Trekking trails & 426 & 5,711 & 6,137 & - & 6,137 \\
\hline Tour operators & 7 & 4,924 & 6,137 & - & - \\
\hline Tourism revenues & - & 47,013 & 47,013 & 47,013 & - \\
\hline Air transport revenues & - & 4,720 & 4,720 & 4,720 & - \\
\hline Restaurant revenues & - & 11 & 11 & 11 & - \\
\hline Total & $\mathbf{1 8 , 8 6 3}$ & $\mathbf{6 2 , 3 7 9}$ & $\mathbf{8 1 , 2 4 2}$ & $75, \mathbf{1 0 5}$ & $\mathbf{6 , 1 3 7}$ \\
\hline Losses under homestays are included under the housing sector and not included in the total \\
\hline
\end{tabular}

Source: NPC, 2015

\section{Public Outreach and Education}

The public should always be kept informed and educated as progress is made in the formulation and implementation of disaster management plan. Usually, disaster management planners underestimate the importance of public education and outreach. Tourism communities have multiple interests who also need to be educated about plan objectives and requirements. It is especially important to educate the stakeholders and their members regarding the integrated plan. Educating communities about the disaster preparedness plan is distinct from the internal communication procedures and requirements needed between agencies (horizontally) and within the disaster management hierarchy (vertically) (UNEP, 2008: 81).

A public outreach and education program for the disaster preparedness plan should consider the following points:

- Develop a Public Outreach Objective and Strategy: This should be a clearly enunciated policy and strategy informed by a specific goal and objective aligned with the overall community-based disaster management strategy. The purpose is to ensure that the outreach efforts are effective and can be digested and transformed into concerted action by the community for all phases of the disaster management cycle. 
o Hotel and resort owners, managers and workers;

o Cruise ship, terminal and pleasure craft operators and workers;

o Industry contract carriage and other operators e.g. tours, attractions, transportation (air, sea, land), diving, entertainment, food and beverage etc.;

o Tourists;

o Tourism industry associations;

o Local population;

o Adjacent and residential communities including schools;

o Hospitals, emergency rooms/triage and other primary care facilities.

Each target group may require differently structured information and messages. Be alert to their particular communication needs in order to focus the outreach exercise. For example, ensure where necessary that the messages are multi-lingual for the spectrum of visitors at the destination. Use also an appropriate combination of signage and pictures for the messages to be conveyed to the illiterate or to those who do not speak the native language (UNEP, 2008: 81).

The earthquake is likely to have inflicted profound impact on the wider economy and mountain livelihoods unless a number of mitigating initiatives are pursued. These efforts need to target the global tourism market and convince potential visitors to come to Nepal, which will help affected tourism entrepreneurs in rural and urban areas (NPC, 2015).

The recovery strategy of NPC has four distinct phases:

- Identify and assess unaffected and safe tourist destinations.

- Create a 'safe trekking system' for mountain tourism in Nepal.

- Rebuild and redevelop damaged areas and enterprises following improved guidelines and regulations of the 'safe trekking system'.

- Identify and develop new tourist products and services. Some of these phases can be sequential or run in parallel depending on the needs.

\section{Way Forward: Back to Normal}

Tharoor (2015) writes that the natural disaster, as many have noted, did not come out of nowhere. For decades, there have been studies showing how prone Nepal is to such temblors, but little was done to prepare for a quake of this magnitude. Experts point to the country's endemic poverty as a reason for its particular vulnerability. The vast international relief mission that has whirred into motion has reinforced the image of a seemingly helpless Nepali state, dependent on outside aid. In the minds of many 
outsiders, Nepal remains a romantic Himalayan destination. Kathmandu, famed for its ancient palaces, is just a gateway to trekking adventures in the shadow of Mount Everest or some of the country's other epic ranges. But this picture-perfect postcard obscures the sweeping, traumatic changes that have racked the country over the past two decades. But the past decade has also seen Nepal lurch from one crisis to the next, the national interest held hostage to the quarrels of feuding political parties. Years of political turbulence have left the Nepali economy in the doldrums, and the Nepali state woefully unable to cope with a tragedy of this size in a country where the infrastructure - from a lack of airports to a shortage of paved roads - is notoriously poor. After a decade of conflict between the government and Maoist insurgents, Nepal's politicians have been too busy battling one another, most recently over constitutional reform, to treat disaster preparedness as a priority. There have been no elections at the district, village or municipal level for almost two decades, and the committees that run local councils aren't organized to coordinate emergency assistance. To be sure, Nepal's political dysfunction is not just the product of incompetent, shortsighted elites.

Despite devastating earthquakes, Nepal is as beautiful as before and its people are just as welcoming. Compare to tourism potential and attractions, damage and loss in tourism sector by the devastating earthquakes was not as massive as it came in media. Even after the earthquakes, most of the tourist trekking routes are safe and fine, except Langtang and Manaslu. Annapurna circuit, one of the best trekking routes in the world (catering $60 \%$ trekkers), Khumbu (catering 20\% trekkers) of Nepal and other trekking routs in eastern and western parts of Nepal have no problem for tourists and are open. Almost 95 percent of all hotels in Nepal are safe and in operation. The internet, telephones and ATM machines are also in operation. There is no danger of any other type of natural calamity or any issues regarding communicable diseases. All hospitals, nursing homes and clinics are well-equipped. All highways are fine. The condition of major tourist destinations, including Pokhara, Lumbini, Palpa, Chitwan, Bardiya, Dolpo, Janakpur and Suklalaphanta are safe well-facilitated for tourists. Nepal has world's top class pilgrimage destinations such as Lumbini, the birthplace of the Buddha, Pashupatinath, Muktinath, Manakamana and many more. Nepal has many places with touristic values and rich cultural traditions. There are some must-visit places so that tourists could understand the Himalaya culture and history in depth. It is the high time to explore Nepal and visit virgin destinations of Nepal (Ghimire 2015).

The Nepali tourism industry requires a strategy that will help manage crises and rapidly implement recovery strategies. After the earthquake, several countries warned their citizens not to visit Nepal unless they were involved in rescue and relief. Nepal could have turned this warning into an opportunity by inviting distinguished guests and goodwill ambassadors such as the UN Secretary General, Hollywood and Bollywood 
stars, sport stars, singers, writers from different countries and diplomatic missions. It could send a strong message to the world, stating that Nepal is open for travel. Nepali embassies and diplomatic missions abroad have been criticized for theirÊincapability to lobby with international communities and branding of Nepal. Nepali ambassadors in different countries should play a proactive role to win back the trust of international community towards visiting Nepal.The Tourism Ministry and the Nepal Tourism Board are failed to coordinate and organize various promotional programs including talks, slide shows, conference presentations, and public relation activities to revive tourism after the earthquakes in Nepal.

Natural disasters can have a devastating effect on tourism. The impact appears bigger than it is. As people from outside donot know the geography, they become confused over the extent of the disaster and the areas affected. Visits to death related sites are not a new phenomenon and people have long been attracted to places or events linked with death and disaster (Biran et al.; 2014: 4).Walters' research shows that there has been a significant increase in the number and intensity of natural disasters in recent years. We have seen the Black Saturday bushfires, the earthquakes in Christchurch and Japan, the floods in Queensland and New Orleans, and the Thai tsunami to name but a few. When disaster hits, the media sensationalise what is happening which draws people's attention to a destination for all the wrong reasons. With events like these becoming more prevalent, we are likely to see more destinations affected. We need to learn lessons from the past to help such locations to restore their tourist trade and rebuild their economy. Whatever the cause of the crisis, Walters' research has shown that there are a number of common steps which destinations can take to limit the damage and project a more positive image (Momentum, 2014):

- Manage the media: Help journalists to understand the damage that sensationalist reporting can cause. Work with them to achieve balanced coverage. Encourage them to be specific about the location of trouble spots to isolate the areas affected, and to cover some stories about positive outcomes as opposed to continually reporting on tragedy and loss. Try to get them involved in some way, for example by giving them a formal role on the tourist board. Educate stakeholders on how to communicate with the media.

- Make use of social media: Use it as a market research tool to assess public opinion and identify emerging trends, and to promote your destination in a positive light. Counter damaging stories in the media with images which directly contradict them - such as tourists relaxing and having fun or hotels and attractions operating as normal in unaffected areas. Encourage tourists to post their own photographs on social media and share them with friends.

- Provide factual information: Give out up-to-date information about safety and the status of attractions, accommodation, restaurants and other facilities. 
Ensure tourists are aware of areas which are not affected so they have alternative destinations within the same area if they need to re-evaluate their travel plans. Providing access to factual and reliable information helps to combat media sensationalism and ensures visitors can make an informed choice.

- Differentiate your destination: In times of crisis, a destination's competitiveness becomes even more important. This is the time to focus on what makes you unique rather than luxury hotels or other facilities that tourists can find elsewhere.

- Donot discount:Research has shown that tourists are not tempted to visit a crisis-hit area solely because of price cuts. Discounting can devalue a destination in the eyes of visitors and once you have cut prices, it's hard to push them up again. It also attracts a fickle audience - consumers who buy on price have no long-term loyalty.

- Beware of being 'open for business' too soon:Announcements of this type should only be made once the whole area is ready and willing to receive visitors. Marketing a destination prior to its full recovery can generate distrust. In the meantime, marketing efforts should be carried out via individual operators within unaffected areas targeting their existing client base directly. In any case, previous visitors are the ones who are most likely to return following a disaster.

- Be prepared: No one likes to acknowledge the risk of disaster but it is worthwhile having a crisis plan in place. This would include helping individual operators to plan for a crisis by considering cancellation policies, evacuation procedures and how the business would survive with no tourist income; preparing marketing messages to roll out following a disaster; and agreeing spokespersons and an effective media management strategy.

- Learn from the past: Look at what measures have been successful in helping other areas to recover. Celebrity endorsements proved highly effective following the bushfires and research suggests that festivals and other events are most valuable in the 12 months to two years following a crisis.

Ying (2011) writes Murphy \&Bayley (1989) suggested that the recovery stage holds a distinctive relationship with tourism from a tourist destinations perspective. At this point, the destination's image of security and pleasure is shattered, to some extent, and whether the recovery is successful or not has a decisive effect on future bookings and economic prospects. They also restated the important role of tourism in terms of attracting visitors back to the affected area quickly and passing the real recovery information from the disaster area to the international community through witnessed visitors. In addition, with the tourists coming, new revenue will be brought to the reconstruction work, which then is greatly able to accelerate the recovery phase. 


\section{Conclusion}

Nepal has to be very optimistic about the future of tourism as it has huge potentials to be the top class tourist destinations. Tourists can experience, enjoy and feel the difference with diverse tourist attractions in Nepal. Nepal can have multiple benefits from tourism. Tourists visiting means directly helping rebuilt the country. Their contribution means a lot to boost up the tourism activities and economy, transform the best technology and practices to the needy ones. There is something called social tourism that includes disaster tourism, volunteering tourism, cultural tourism, heritage tourism, responsible tourism, educational tourism, medical and relief tourism which is the act of travelling to a disaster areas as a matter of curiosity and generosity that ultimately gives them a satisfaction. Any time is good time to visit Nepal. Everybody travel for fun but tourists can make difference while visiting Nepal in this difficult situation and make it the most fulfilling trip. However, the government and tourism entrepreneurs should assure tourists for quality services and their safety. If they are satisfied with their visit, it will have multiple benefits such as lengthening their stay period, repeat visits, recommend to the friends and relatives, videos posting and writeups about their trips in Nepal and many more.

The damages caused to the tourism sector in Nepal by the April 25 earthquake and powerful aftershocks were wrongly reported in the international community. Only some tourist sites suffered damages, while most destinations favored by tourists are remained unaffected. It is unfortunate that it has been miscommunicated among foreigners that almost all tourist destinations are damaged. Tourist arrivals in Nepal after the quake have been affected and declined, however, Nepal should take serious efforts to convince foreigners to visit Nepal and revive immediately. Likewise, the government and tourism stakeholders should seriously follow the code of conducts, modules and innovative activities to handle the difficult situation after disasters, strategies of risks and crisis management, and marketing plans for sustainable tourism development in Nepal.

\section{References:}

APEC(2006). Tourism Risk Management - An Authoritative Guide to Managing Crises in Tourism. Asia-Pacific Economic Cooperation (APEC) (Retrieved from: http://www.crctourism.com.au/wms/upload/resources/aicst/06_twg_riskmgmt_ Guide\%20eng.pdf)

Biran, A., Liu, W., Li, G., \&Eichhorn, V. (2014). Consuming post-disaster destinations: The case of Sichuan, China. Annals of Tourism Research, 47, 1-17 (Retrieved from: http://epubs.surrey.ac.uk/805641/1/Biran\%20Consuming\%20PostDisaster\%20Destinations\%20FULL\%2014-01-14.pdf).

Ghimire, H.L. (July 15, 2015). Naturally Nepal, Despite devastating earthquakes, Nepal is as beautiful as before and its people are just as welcoming. Kathmandu Post. Kathmandu: Kantipur Publications. 
Ghimire, H.L. (May 30, 2015). BhukampapachhikoNepalkoparyatan. Kantipur daily. Kathmandu: Kantipur Publications.

Ghimire, H.L. (2014). Social Tourism: An Alternative Tourism in Nepal. THE GAZE Journal of Tourism and Hospitality. Kathmandu: International School of Tourism and Hotel Management (Affiliated to Salzburg University of Applied Sciences, Austria), 6 (1):98-118.

IFRC (2015). What is a disaster? International Federation of Red Cross and Red Crescent Societies (IFRC) (Retrieved from: https://www.ifrc.org/en/what-wedo/disaster-management/about-disasters/what-is-a-disaster/).

Faulkner, B. (2001). Towards a framework for tourism disaster management. Tourism Management, 22 (2): 135-147 (Retrieved from: http://www.ingentaconnect. com/content/els/02615177/2001/00000022/00000002/art00048).

Kunwar, R.R. (2015). Tourism and Natural Disaster: A Study of Nepal's Earthquake -2015. Voice of Himalaya. Kathmandu: Mountain Academy Nepal, 4 (1): 19-37.

Kunwar, R.R. \&Limbu, B. (2015). Tourism and Earthquake: A Case Study of Nepaluilding Better Tourism With Renewed Strength (XXth NATTA Convention). Kathmandu: NATA.

Mistilis, N \& Sheldon, P.J. (2005). Knowledge Management for Tourism Crises and Disasters (Retrieved from: http://wwwdocs.fce.unsw.edu.au/marketing/ Mistilis05_ 2.pdf).

Momentum (October, 2014). Rebuilding tourism in the wake of disaster. Momentum The business magazine of UQ Business School (Retrieved from: http://www.business. uq.edu.au/momentum/rebuilding-tourism-wake-disaster).

NDMRH (2015). Nepal Disaster Management Reference Handbook (NDMRH). Center for Excellence in Disaster Management \& Humanitarian Assistance (Retrieved from https://www.cfe-dmha.org/LinkClick.aspx?fileticket= xEUbtKHdfR4\%3D\&portalid=0).

NPC (2015). Nepal Earthquake 2015 Post Disaster Need Assessment. Kathmandu: Government of Nepal, National Planning Commission (NPC) (Retrieved from: http://www.npc.gov.np/web/new/uploadedFiles/allFiles/PDNA-excutive Summary.pdf).

Tharoor, I. (April 27, 2015). Nepal's other disaster: Its politics. The Washington Post (Retrieved from: https://www.washingtonpost.com/news/worldviews/ $\mathrm{wp} / 2015 / 04 / 27 /$ nepals-other-disaster-its-politics/).

Tourism review (2015). Fuel Shortage Hampers Tourism in Nepal. Tourism Review (Retrieved from: http://www.tourism-review.com/tourism-in-nepal-hit-by-fuelemergency-news4780). 
UNEP (2008). Disaster Risk Management for Coastal Tourism Destinations Responding to Climate Change A Practical Guide for Decision Makers. United Nations Environment Programme (UNEP) (Retrieved from: http://www.unep.org/PDF/ DisasterRiskManagementforCoastalTourism_April_09.pdf).

UNISDR (2015). 25 April 2015 Gorkha Earthquake Disaster Risk Reduction Situation Report. The United Nations Office for Disaster Reduction (UNISDR). (Retrieved from: http://www.preventionweb.net/files/44592_ gorkhaearthquake disasterriskreducti.pdf)

Ying, L. (2011). Developing a Post-disaster Sustainable Tourism ModelForTourism Revitalization: Analysis of Sichuan's Response to the WenchuanEarthquake in 2008. (Retrieved from: http://r-cube.ritsumei.ac.jp/bitstream/10367/3920/1/ 51210001.pdf).

http://www.oxforddictionaries.com/definition/english/disaster 